\title{
Ecological Consequences of Pathogen and Insect Invasions
}

\author{
Patrick C. Tobin
}

Published online: 30 January 2015

(C) Springer International Publishing AG 2015

\begin{abstract}
The introduction and successful establishment of nonnative species poses a significant threat to the function and structure of native ecosystems and biodiversity. Forest ecosystems are especially threatened due to the worldwide importance of wood packaging material universally used in global trade, the importation of lumber and wood products, and the importation of live trees for planting. This collectively enables a number of invasion pathways that facilitate the introduction of forest insects and pathogens. Consequently, forest ecosystems worldwide are under threat from nonnative forest pest species, many of which pose little concern in their native habitats due to the checks and balances associated with natural enemies and host plant defensive responses. Unfortunately, the lack of concern for many species in their native habitats leads to a significant knowledge gap when such species are introduced into a new environment and begin to pose negative ecological consequences. In this review, I discuss variation in establishment success and ecological consequences exerted by nonnative forest insects and pathogens, define characteristics of high-impact species, and review recent research on the ecological consequences of these highimpact species in forest ecosystems. Although specific insect and pathogen examples are drawn from invasions in North American forest ecosystems, the concepts of habitat invasibility, species invasiveness, and the ecological consequences expressed by nonnative forest species are not unique to North America.
\end{abstract}

This article is part of the Topical Collection on Forest Pathology and Entomology

\section{P. C. Tobin $(\triangle)$}

School of Environmental and Forest Sciences, University of

Washington, 123 Anderson Hall, 4000 15th Avenue NE,

Seattle, WA 98195-2100, USA

e-mail: pctobin@uw.edu
Keywords Biological invasions $\cdot$ Habitat invisibility · Forest ecosystem $\cdot$ Species invasiveness

\section{Introduction}

The introduction and establishment of species in new habitats has continuously occurred throughout the world's history and long before the arrival of humans and their immediate ancestors. Undoubtedly, some of these new species caused dramatic and cascading changes to native biodiversity and ecosystem function. The joining of the North and South American continents, for example, following the rise of the Isthmus of Panama during the Pliocene Epoch led to numerous interchanges of species along this newly formed land bridge [1]. This event certainly placed species with no prior evolutionary history into competition, which led to species extinctions and provided Alfred Russel Wallace with supporting evidence in his development of the concept of biogeography [2].

But while the interchange of species in the early stages of the Earth's history followed the formation of land bridges or other geological phenomenon that developed over millions of years, today's trends of global trade and travel have greatly facilitated the accidental hitchhiking of species on an unprecedented scale [3-5]. The world's busiest ports handle 10 million to more than 30 million 20-foot equivalent units of cargo each year [6]. Global forests are particularly challenged by trade pathways due to the widespread use of wood in packaging material such as crates, pallets, and dunnage, as well as the importation of wood, wood products, and live plants [7, 8, 9•, $10,11]$. Consequently, there is a vast number of vehicles on which forest insects and pathogens can be accidently transported and subsequently introduced into a new environment. 
Unfortunately, development of a broadly applicable paradigm useful to predict the invasiveness of a species has remained elusive, which is not terribly surprising given the tremendous variation in species life history traits and the unpredictable stochasticity associated with a species when it is introduced to a new habitat. Thus, this review will consider only broad conceptual hypotheses that have been proposed to explain variation in both rates of establishment and variation in the amount of ecological damage caused by nonnative species. I will then focus on the characteristics of high-impact nonnative forest insects and pathogens and review recent research on the ecological consequences of these high-impact species in forest ecosystems.

\section{Variation in Rates of Establishment}

Fortunately, most hitchhiking species are thought to fail to establish successfully when arriving to a new area $[12,13]$, and establishment is not a trivial obstacle [14, 15]. For example, to successfully establish in a new area, a species must be in a life stage that is conducive to surviving the voyage. It must also arrive under conditions favorable to its survival, such as arriving during the appropriate season given its phenological stage, as well as arriving in an area with a climate reasonably similar to its native range. The degree of habitat invasibility to which a new species arrives is also an important consideration. Habitats that are generally more likely to support successful establishment of an introduced species (e.g., high invasibility) are thought to be characterized by an availability of resources, higher levels of disturbance, and the lack of competitors and regulators [16-20]. For example, one hypothesis, the diversity-invasibility hypothesis, suggests that habitats with greater biodiversity are more resistant to invasion due to less available resources, and consequently less available niches, and a greater potential for a diverse natural enemy complex [21]. Because nonnative species tend to reduce native biodiversity, the continual establishment of nonnative species could initiate a cycle of reduced biodiversity followed by a consequent increase in habitat invasibility. However, many prior studies have observed a positive association between native and nonnative species richness, giving rise to a contradiction known as the invasion paradox [22].

Regardless of the drivers of habitat invasibility, an extremely important constraint, and perhaps the most critical constraint, to successful initial establishment is the sheer number of individuals that are actually transported and arrive in a new area alive. Several previous studies across taxa have highlighted the positive association between founder population size and rates of successful establishment [23-27]. Indeed, population size is an important component of the dynamics of any species and garners much attention from conservation biologists when managing low-density populations that are at risk of extinction [28]. Inversely, nonnative species face similar challenges when attempting to establish and maintain a reproductively viable population when initiated at low densities [29]. Low-density populations can be subject to both demographic and environmental stochasticity, resulting in lower population growth rates [30]. The genetic architecture of the founder population can also influence establishment success [31]. Populations founded by fewer individuals generally have lower genetic diversity, which can produce a genetic bottleneck that could limit invasion success [32]. Finally, lowdensity populations can be subject to Allee effects (e.g., positive-density dependence [33-37]). The concept of Allee effects is based on the assertion that populations must comprise a minimum number of individuals to remain reproductively viable such that below this threshold populations are unable to replace themselves and instead are driven towards extinction [38]. Populations that are too small could challenge individuals to locate suitable mates, satiate natural enemies, or overcome host defensive responses [39, 28, 40, 41].

Unfortunately, despite these seemingly insurmountable challenges, some species do successfully establish in a new area upon their arrival, and some fraction of these species ultimately cause extensive ecological impacts when released into a novel habitat $[12,42,43]$. Moreover, in addition to the observation that not all introduced species cause disturbance when introduced into a new ecosystem, it is also important to note that many insects and pathogens posing severe ecological consequences in a novel environment are not regarded as pests in their native regions. To some extent, this is of major significance, as species not considered to be pests are not always studied as thoroughly as those that are pests. Consequently, when a new species is introduced to a new habitat and begins to pose ecological consequences, there is often a lack of information from the literature, such as research on its basic biology and ecology, host range, and appropriate control tactics, which could otherwise be useful in management efforts [44]. Although there is no rule that can be applied generally across taxa to estimate the potential for a specific nonnative species to detrimentally affect ecosystems, there are two concepts to consider: the enemy-release hypothesis and the defense-free space hypothesis.

\section{Variation in Ecological Consequences}

The enemy-release hypothesis describes the phenomenon in which a newly arrived species is free from the natural enemy complex that is present in its native habitat [45]. In the absence of such top-down enemies, important and potentially regulatory constraints are removed, thereby allowing for greater population growth through, for example, increased survivorship [46]. Insects in particular can be attacked by a number of generalist and specialist natural enemies in their native 
environment, and such natural enemies are generally not introduced with their prey, although there are some exceptions, especially in the case of entomopathogens [47]. Historically, the enemy-release hypothesis has been cited as a primary mechanism through which an invading species becomes a particularly noxious one [48].

An example of the importance of natural enemies in providing invasive species control can be provided by the case of the brown-tail moth, Euproctis chrysorrhoea, invasion of the USA. Life stages of the brown-tail moth are believed to have been introduced from Europe on infested nursery stock in 1897 [49]. It quickly spread throughout the northeastern USA, where it caused severe defoliation to a number of host tree species [50]. However, following the importation of a natural enemy, the generalist parasitoid Compsilura concinnata, one of many such species introduced from Europe during biological control efforts spearheaded by the US Department of Agriculture to combat nonnative insect pests [51], populations dramatically declined. Nowadays, populations of E. chrysorrhoea are extremely restricted to dune habitats along Cape Cod where C. concinnata cannot persist [52]. Despite this example supporting the enemy-release hypothesis, this hypothesis provides only a partial explanation to the success of nonnative pests given that only a minority of established nonnative species cause severe ecological impacts in a novel environment, and the number of nonnative species posing little to no damage even in the absence of natural enemies [53].

The defense-free hypothesis can be considered as the bottom-up analog to the enemy-release hypothesis [54]. In a native environment, species generally evolve in close concert with that of their hosts, and insects and plant pathogens are no exception. Studies of plants and their interactions with herbivores and plant pathogens are extremely numerous, and many have collectively described the exciting chemical warfare between the two trophic levels (e.g., [55-57]). Plants produce constitutive, and when attacked, inducible chemical compounds that can reduce growth and digestion and induce mortality in the attacking herbivore [58, 59]. Natural enemies can also detect some defensive compounds and respond by attacking the plant-attacking herbivore [60]. This warfare is hardly one-sided, as insect herbivores and pathogens are capable of metabolically neutralizing the otherwise inimical effects of plant chemical compounds produced by their native host plants [61], or developing behavioral mechanisms, such as mass-attacks exhibited by some bark beetle species, to overwhelm the plant defensive capability [62]. However, these extremely intricate relationships between native plants, and their attacking pathogens and herbivores, do not always persist when insects and pathogens attack naïve host plants with which they have no prior evolutionary history $[63,64]$. In such cases, plant defensive compounds are not always as effective as they would be against native insects and pathogens.
An example of the vulnerability of naïve host plants against attack by nonnative species can be found in congener species of Agrilus. One species, the bronze birch borer Agrilus anxius, is native to North America where it causes considerable mortality to nonnative birch [Betula spp.] species planted in North America, while native birch species are rarely killed [65]. Similarly, the emerald ash borer, Agrilus planipennis, which is native to Asia but was discovered in North America in 2002 [66], is causing extensive mortality to all species of North American ash [Fraxinus spp.], while ash species native to Asia are resistant [67]. The relationship between naïve host plants and nonnative species is certainly not limited to nonnative insects; indeed, one of the most dramatic changes to eastern forests in the USA followed the accidental importation of the fungus Cryphonectria parasitica, the causative agent of chestnut blight. This fungus is believed to have been imported from Asia through infested nursery stock in the early 1900s. By the 1940s, virtually all mature chestnuts, Castanea dentata, native to North America, which were once a dominant component of many eastern forests, were eliminated by this pathogen $[68,69 \bullet \bullet$. One current effort to restore chestnut to North America involves developing backcrossed blightresistant chestnut trees using Chinese chestnut, Castanea japonica (a natural host of $C$. parasitica), as a genetic source of resistance [70].

\section{High-Impact Nonnative Insects and Pathogens}

Regardless of the mechanism(s) that otherwise would provide resistance against a nonnative species and its ability to disrupt ecological processes in a new environment, certain introduced species have caused major ecological consequences and dramatically altered and continue to alter the ecological landscape. Aukema et al. [43] estimated that between 1860 and $2006, \approx 2.5$ insects arrived and successfully established in the USA per year, but only $\approx 0.4$ insects per year were considered to be high-impact pests. But what makes a particular nonnative species a "high impact" one? Although there are examples of species whose impacts include the potential loss of susceptible host tree species (i.e., C. parasitica and C. dentata, A. planipennis and North American Fraxinus spp.), ecological impact can often be a question of scale. For example, nonnative species attacking a spatially limited host, resulting in localized ecological disturbance, may not garner the attention of a more spatially widespread problem; yet, the localized consequences can still be profound, if merely on a smaller scale.

There are several characteristics of a high-impact nonnative species in forest ecosystems. First, such species tend to exhibit a high potential for population growth, and certainly a lack of top-down (e.g., effect of natural enemies) and/or bottom-up (e.g., effect of host plant chemistry) mechanisms plays a role in this population success. Second, the ecological 
consequences they cause are ultimately significantly greater than the background level of disturbance. However, it is also important to note that during the initial stages of a forest insect or pathogen invasion, impacts are often initially limited and not readily apparent, which results in a latency period following arrival and establishment, and growth to sufficiently detectable damage levels [15]. Third, high-impact forest pest species often cause disturbance over a spatially widespread and/or contiguous area, which poses numerous consequences. For example, large areas exhibiting disturbance can overwhelm the budgetary and logistical abilities of regulatory agencies to suppress populations and thereby mitigate impacts [71]. Widespread disturbance caused by high-density populations of nonnative species can also dilute the control effects of natural enemies, as well as reduce the landscape's ability for buffering due to simultaneous disturbance $[72,73]$.

\section{Ecological Consequences of High-Impact, Nonnative Insects and Pathogens}

There have been two recent reviews that have addressed the ecological consequences of nonnative pathogenic fungi [69・•] and nonnative insects [74••] in forest ecosystems. My goal is not to duplicate these efforts but to summarize them along with other recent advances in our knowledge of the ecological consequences of nonnative forest pests. A summary of some nonnative insect and pathogens affecting North American forests is presented in Table 1, and highlights the diversity in origin, presumed invasion pathway, and ecological damage among insect and pathogen invaders. Regardless of the causative species, the most visible consequence of high-impact nonnative forest pests is the direct effects to host trees, such as defoliation, die-back, branch failures potentially resulting in damage to household property, and tree death. There is tremendous variation in the amount of ecological impacts among nonnative forest pests, which can furthermore be expressed differently across forest types and climate zone. Some feeding guilds are generally more destructive given the nature of their attack. For example, wood and subcortical phloem feeders, such as A. planipennis, actively disrupt nutrient flow and, when extensive, can cause tree death either directly or indirectly by making the host more susceptible to attack by other organisms, including native species. Similarly, symbiotic interactions between the walnut twig beetle, Pityophthorus juglandis, which is native to North America, and the nonnative fungal pathogen Geosmithia morbida can also disrupt nutrient flow, leading to the disease known as thousand cankers disease. This disease was first detected in eastern North America in 2010 after being known in the western USA and has the potential to cause significant decline in eastern walnut [Juglans spp.] species [75]. In most cases, visual signs of tree decline due to nutrient flow disruption, whether due to insect or pathogen, are not readily apparent. Rather, only after years of attack are signs of tree decline above human detectable thresholds. Indeed, a recent analysis of forest insect eradication programs highlighted the challenges in successfully eradicating insect pests whose initial signs of feedings are internal and not immediately visible [76].

In contrast, the direct damage to host trees by insect defoliators and leaf or needle pathogens is often more visually apparent; indeed, a denuded tree in summer is a hard sign to miss. However, the build-up to such defoliating populations or the presence of a high abundance of pathogenic activity is not always rapid, even in the absence of natural enemies and in the presence of naïve and suitable host trees. For example, following the introduction of the gypsy moth, Lymantria dispar, by E. Leopold Trouvelot at 27 Myrtle Street, Medford, Massachusetts, in 1879, it took over 10 years for larval population densities to be high enough and of sufficient nuisance to be detected by the neighbors residing at 29 Myrtle Street [77].

Regardless of the insect-feeding guild, the symbiotic interaction between an insect and a plant pathogen, or the independent effects of a plant pathogen, the ecological consequences of tree decline and/or death are profound. When such declines are present in the urban forest, the additional economic costs can be staggering. Tree death in the urban forest poses immediate safety and consequent liability concerns [78]. A recent study on the costs of oak wilt, caused by the pathogen Ceratocystis fagacearum, in the Minnesota urban forest showed that the bulk of costs due to this nonnative pathogen are associated with hazard tree removal on public and private lands [79]. Similar results were estimated for economic impacts of A. planipennis in Ohio [80]. Even in the case of a defoliator such as $L$. dispar, which is not a direct tree killer (as most defoliated trees will recover), hazard tree removal was estimated to represent approximately half of the costs associated with an outbreak in the urban forest [81].

Tree decline and death in the urban forest also can affect a number of other processes, including increased energy consumption in summer due to a lack of shading, decreased pollutant uptake and carbon emission sequestration, decreased property values, and increased consumer costs associated with dead tree removal on private lands [82]. Dead and dying trees, in any landscape, also provide a food source for ambrosia beetles. Although ambrosia beetles in general tend to attack already dead or dying host trees and thus have not historically been a major threat to live trees, some recently introduced species, such as Xylosandrus germanus, have shown an ability to attack stressed but otherwise healthy native trees [83]. Also, as with all ambrosia beetles, the nonnative red bay ambrosia beetle, Xyleborus glabratus, carries a symbiotic fungus that causes laurel wilt, and has been observed to be a cause of tree decline and death in several host trees species in the southeastern USA [84]. The accumulation of dead wood and down woody material through the action of nonnative forest pests 
Table 1 Exemplar nonnative insect and pathogens affecting North American forests

\begin{tabular}{|c|c|c|c|c|c|}
\hline Species & $\begin{array}{l}\text { Introduced } \\
\text { from }\end{array}$ & $\begin{array}{l}\text { Year } \\
\text { introduced }\end{array}$ & $\begin{array}{l}\text { Likely introduction } \\
\text { pathway }\end{array}$ & Susceptible host plants & Damage \\
\hline $\begin{array}{l}\text { Insect-gypsy moth, } \\
\text { Lymantria dispar }\end{array}$ & Europe & 1869 & Imported life stages & $\begin{array}{l}>300 \text { host trees, } \\
\text { including oak, } \\
\text { willow, and birch }\end{array}$ & $\begin{array}{l}\text { Defoliator, periodically defoliating } \\
\text { large forest areas; tree death could } \\
\text { occur after repeated years of } \\
\text { defoliation } \\
\text { or through opportunistic organisms }\end{array}$ \\
\hline $\begin{array}{l}\text { Insect_emerald ash } \\
\text { borer, Agrilus } \\
\text { planipennis }\end{array}$ & Asia & $\begin{array}{l}\text { At least by } \\
2002\end{array}$ & $\begin{array}{l}\text { Solid wood packaging } \\
\text { material }\end{array}$ & $\begin{array}{l}\text { All North American } \\
\text { ash species }\end{array}$ & $\begin{array}{l}\text { Wood borer causing tree death; possible } \\
\text { long-term consequences include the } \\
\text { functional extinction of North } \\
\text { American ash }\end{array}$ \\
\hline $\begin{array}{l}\text { Insect }- \text { hemlock } \\
\text { woolly adelgid, } \\
\text { Adelges tsugae }\end{array}$ & Japan & $1950 \mathrm{~s}$ & Infested nursery stock & $\begin{array}{l}\text { Eastern and Carolina } \\
\text { hemlock }\end{array}$ & $\begin{array}{l}\text { Feed on ray parenchyma cells; causing } \\
\text { extensive hemlock mortality in } \\
\text { eastern forests }\end{array}$ \\
\hline $\begin{array}{l}\text { Pathogen - chestnut blight, } \\
\text { Cryphonectria parasitica }\end{array}$ & Asia & $\begin{array}{r}\text { Around } \\
1900\end{array}$ & Infested nursery stock & American chestnut & $\begin{array}{l}\text { Girdles stem resulting in tree death. } \\
\text { American chestnut mostly eliminated } \\
\text { by } 1940\end{array}$ \\
\hline $\begin{array}{l}\text { Pathogen — beech bark disease, } \\
\text { Neonectria faginata }\end{array}$ & Europe & 1890 & Infested nursery stock & American beech & $\begin{array}{l}\text { Girdles stem resulting in tree death. } \\
\text { Action } \\
\text { involves the interaction between the } \\
\text { pathogen and an insect, beech scale } \\
\text { (Cryptococcus fagisuga) }\end{array}$ \\
\hline $\begin{array}{l}\text { Pathogen-Dutch elm disease, } \\
\text { Ophiostoma ulmi, O. novo- } \\
\text { ulmi }\end{array}$ & Europe & $\begin{array}{l}\text { At least by } \\
1928\end{array}$ & $\begin{array}{l}\text { Infected elm bark beetles } \\
\text { residing in wood } \\
\text { imports }\end{array}$ & Elm species & $\begin{array}{l}\text { Vascular wilt disease causing } \\
\text { death. Transmitted by nonnative } \\
\text { and native elm bark beetles }\end{array}$ \\
\hline
\end{tabular}

could synergistically provide an additional food resource for nonnative ambrosia beetles, which are seemingly able to exploit healthier naïve host trees $[85,86]$. Thus, this potentially compounds the threat of nonnative ambrosia beetles in novel habitats and especially to naïve host trees that could have less effective plant chemical defense response.

Although the costs associated with dead trees in traditional forested areas and wildlands may not include hazard tree removal, effects to native biodiversity can be considerably more severe. Urban forests certainly harbor a degree of native biodiversity, and recent attention given to the role of urban species in providing ecosystem services is surely warranted [87]. Undoubtedly, there are negative effects of nonnative forest pests to urban ecosystem services, and species that depend on urban trees affected by nonnative forest pests are directly and indirectly affected in similar ways as traditional forested areas. However, traditional forested areas and wildlands tend to represent a greater wealth of native biodiversity, and thus, the negative effects of nonnative forest pests, aside from a loss of host tree resources, can be dire.

One direct negative biological effect of nonnative forest pests is competition with native species for resources [74••, $69 \bullet \bullet$; these competitive interactions could also favor nonnative species when the defense-free space of naïve host trees is exploited. Furthermore, indirect effects may amplify negative impacts on native species; for example, native species associated with similar host trees of the gypsy moth suffered increased rates of parasitism by generalist parasitoids in the presence of increased gypsy moth populations [88].

Management responses to nonnative forest pests could also directly and indirectly affect nontarget native species, despite the best intentions [89]. Management options for nonnative forest pests include the removal of host material as a means to provide a barrier zone around an infested area [90], thereby not only limiting population spread but also removing host material for native species. Another option is aerial applications of pesticides, such as formulations of the biopesticide Bacillus thuringiensis kurstaki (Btk) [71]. Although Btk is specific to Lepidoptera, there are reports of short-term effects to nontarget species with cascading effects to higher trophic levels, such as birds, that depend on caterpillars as a food source $[74 \bullet \bullet]$. Other pesticide applications, such as the broad spectrum diflubenzuron, can interfere with the synthesis of chitin during the molting process of all arthropods [91] and affect higher trophic levels [92]. However, it is important to consider the potential positive effects of management tactics as well as the potential negative effects to nontarget native species. For example, a recent study demonstrated that the direct effect of $L$. dispar defoliation had a much greater negative impact to nontarget species, and especially to Geometrids, than did applications of Btk deployed to mitigate outbreaking L. dispar populations [93].

In addition to the direct effects of nonnative forest pests on other organisms, for example through competition, or 
indirectly through, for example, alterations in food web dynamics, forested areas disturbed by nonnative insects and pathogens also result in changes to ecosystem processes. Defoliation by nonnative forest pests can affect the biogeochemistry of terrestrial and aquatic communities [72, 94-96]. For example, large-scale defoliation by $L$. dispar significantly altered stream quality by altering water $\mathrm{pH}$ and increasing nitrate levels [97], with potential consequences to aquatic organisms. Invasions by nonnative forest pests can also result in considerable amounts of dead and down woody material, and areas of extensive tree mortality provide a fuel source for forest fires [98] that are becoming an increasing concern, especially at forest-urban interface. Forests containing trees killed by nonnative pests are often characterized by nearsimultaneous mortality, which opens immediate and largescale gaps. Such a large-scale disturbance event, especially when compressed over a smaller time scale, provides an opening for pioneer species, which nowadays more than likely includes nonnative plants that can both dominate the landscape as well as completely alter food web relationships that previously existed $[99,100]$.

\section{Conclusions}

Unfortunately, invasions by nonnative insects and pathogens will continue to affect forest ecosystems given our collective demand for worldwide goods that necessitates the current rate of imports and exports. Primary obstacles in stemming the tide of nonnative species introduction undoubtedly include the sheer quantity of trade imports, the lack of sufficient regulatory resources allocated to prevent their introduction at portsof-entry, and the proverbial "known unknowns" associated with species introductions. In other words, the importance of global trade as a pathway for nonnative species introduction is undeniably understood $[9 \cdot 11,8]$; yet, it is nearly impossible to predict exactly what new species will be introduced at a given time and where it will appear. Moreover, a recent study suggested that $72 \%$ of infestations on imported live plants evaded detection efforts by US plant inspectors at ports-ofentry [9•]. Even in New Zealand, a country considered to have one of the more robust biosecurity programs in the world, only approximately $10 \%$ of consignments are examined by quarantine officers given the sheer number of imports [7]. Although regulatory emphasis on pests with a high-likelihood of introduction, given the timing and direction of global trade routes, is useful, it is challenging to envision any feasible mechanism to eliminate nonnative species introductions under current patterns of global trade. The unfortunate reality is the continual introduction of high-impact species, likely similar to the historical rate of 0.4 insects per year reported by Aukema et al. [43]. Efforts to synthesize our knowledge of the life history traits that facilitate a species to be an efficient invader, and the habitat characteristic that enable species invasions, will continue to be in high demand to mitigate the inevitable ecological consequences of nonnative forest insects and pathogens.

\section{Compliance with Ethics Guidelines}

Conflict of Interest Statement Dr. Tobin has no conflicts of interests to declare.

Human and Animal Rights and Informed Consent This article contains no studies with human or animal subjects performed by the author.

\section{References}

Papers of particular interest, published recently, have been highlighted as:

- Of importance

•• Of major importance

1. Marshall LG, Webb SD, Sepkoski Jr JJ, Raup DM. Mammalian evolution and the great American interchange. Science. 1982;215: 1351-7.

2. Wallace AR. The geographical distribution of animals. With a study of the relations of living and extinct faunas as elucidating the past changes of the earth's surface, vol. 1-2. New York: Harper and Brothers; 1876.

3. Mack RN, Simberloff D, Lonsdale WM, Evans H, Clout M, Bazzaz FA. Biotic invasions: causes, epidemiology, global consequences, and control. Ecol Appl. 2000;10:689-710.

4. Lockwood JL, Hoopes M, Marchetti M. Invasion ecology. Malden: Blackwell Publishing Ltd.; 2007.

5. Reichard SH, White P. Horticulture as a pathway of invasive plant introductions in the United States. Bioscience. 2001;51:103-13.

6. Salisbury M. The JOC top 50 world container ports. J Comm August. 2012;20-27:24-30.

7. Brockerhoff EG, Bain J, Kimberley M, Knížek M. Interception frequency of exotic bark and ambrosia beetles (Coleoptera: Scolytinae) and relationship with establishment in New Zealand and worldwide. Can J For Res. 2006;36:289-98.

8. Work TT, McCullough DG, Cavey JF, Komsa R. Arrival rate of nonindigenous insect species into the United States through foreign trade. Biol Invasions. 2005;7:323-32.

9. Liebhold AM, Brockerhoff EG, Garrett LJ, Parke JL, Britton KO. Live plant imports: the major pathway for forest insect and pathogen invasions of the United States. Front Ecol Environ. 2012;10: 135-43. Provides an analysis of live plant imports, which are the primary pathway for forest insect and pathogen invasions.

10. Dehnen-Schmutz K, Touza J, Perrings C, Williamson M. A century of the ornamental plant trade and its impact on invasion success. Divers Distrib. 2007;13:527-34.

11. McCullough DG, Work TT, Cavey JF, Liebhold AM, Marshall D. Interceptions of nonindigenous plant pests at US ports of entry and border crossings over a 17-year period. Biol Invasions. 2006;8: 611-30.

12. Williamson M, Fitter A. The varying success of invaders. Ecology. 1996;77:1661-6.

13. Ludsin SA, Wolfe AD. Biological invasion theory: Darwin's contributions from the origin of species. Bioscience. 2001;51:780-9. 
14. Jerde CL, Lewis MA. Waiting for invasions: a framework for the arrival of non-indigenous species. Am Nat. 2007;170:1-9.

15. Liebhold AM, Tobin PC. Population ecology of insect invasions and their management. Annu Rev Entomol. 2008;53:387-408.

16. Davis MA, Grime JP, Thompson K. Fluctuating resources in plant communities: a general theory of invasibility. J Ecol. 2000;88: $528-34$.

17. Tilman D. Community invasibility, recruitment limitation, and grassland biodiversity. Ecology. 1997;78:81-92.

18. Ohlemüller R, Walker S, Bastow WJ. Local vs. regional factors as determinants of the invasibility of indigenous forest fragments by alien plant species. Oikos. 2006;112:493-501.

19. Crawley MJ. What makes a community invasible? In: Gray AJ, Crawley MJ, Edwards PF, editors. Colonization, succession and stability. Oxford: Blackwell; 1987. p. 429-53.

20. Lonsdale WM. Global patterns of plant invasions and the concept of invasibility. Ecology. 1999;80:1522-36.

21. Tilman D. The ecological consequences of changes in biodiversity: a search for general principles. Ecology. 1999;80:1455-74.

22. Fridley JD, Stachowicz JJ, Naeem S, Sax DF, Seabloom EW, Smith MD, et al. The invasion paradox: reconciling pattern and process in species invasions. Ecology. 2007;88:3-17.

23. Beirne BP. Biological control attempts by introductions against pest insects in the field in Canada. Can Entomol. 1975;107:22536.

24. Lockwood JL, Cassey P, Blackburn T. The role of propagule pressure in explaining species invasions. Trends Ecol Evol. 2005;20: 223-8.

25. Memmott J, Craze PG, Harman HM, Syrett P, Fowler SV. The effect of propagule size on the invasion of an alien insect. J Anim Ecol. 2005;74:50-62.

26. Simberloff D. The role of propagule pressure in biological invasions. Annu Rev Ecol Evol Syst. 2009;40:81-102.

27. Whitmire SL, Tobin PC. Persistence of invading gypsy moth populations in the United States. Oecologia. 2006;147:230-7.

28. Courchamp F, Berec L, Gascoigne J. Allee effects in ecology and conservation. Oxford: Oxford University Press; 2008.

29. Tobin PC, Berec L, Liebhold AM. Exploiting Allee effects for managing biological invasions. Ecol Lett. 2011;14:615-24.

30. Lande R. Risks of population extinction from demographic and environmental stochasticity and random catastrophes. Am Nat. 1993;142:911-27.

31. Lee CE. Evolutionary genetics of invasive species. Trends Ecol Evol. 2002;17:386-91.

32. Hufbauer RA, Rutschmann A, Serrate B, Vermeil de Conchard H, Facon B. Role of propagule pressure in colonization success: disentangling the relative importance of demographic, genetic and habitat effects. J Evol Biol. 2013;26:1691-9.

33. Lewis MA, Kareiva P. Allee dynamics and the spread of invading organisms. Theor Popul Biol. 1993;43:141-58.

34. Stephens PA, Sutherland WJ, Freckleton RP. What is the Allee effect? Oikos. 1999;87:185-90.

35. Taylor CM, Hastings A. Allee effects in biological invasions. Ecol Lett. 2005;8:895-908.

36. Tobin PC, Whitmire SL, Johnson DM, Bjørnstad ON, Liebhold AM. Invasion speed is affected by geographic variation in the strength of Allee effects. Ecol Lett. 2007;10:36-43.

37. Courchamp F, Clutton-Brock T, Grenfell B. Inverse density dependence and the Allee effect. Trends Ecol Evol. 1999;14:405-10.

38. Allee WC. The social life of animals. New York: W.W. Norton and Company, Inc.; 1938.

39. Berec L, Angulo E, Courchamp F. Multiple Allee effects and population management. Trends Ecol Evol. 2007;22:185-91.

40. Stephens PA, Sutherland WJ. Consequences of the Allee effect for behaviour, ecology and conservation. Trends Ecol Evol. 1999;14: 401-5.
41. Tobin PC, Onufrieva KS, Thorpe KW. The relationship between male moth density and female mating success in invading populations of Lymantria dispar. Entomol Exp Appl. 2013;146:10311.

42. Simberloff D, Gibbons L. Now you see them, now you don't!Population crashes of established introduced species. Biol Invasions. 2004;6:161-72.

43. Aukema JE, McCullough DG, Von Holle B, Liebhold AM, Britton K, Frankel SJ. Historical accumulation of nonindigenous forest pests in the continental US. Bioscience. 2010;60:886-97.

44. Government Accountability Office (2006) Invasive forest pests. Lessons learned from three recent infestations may aid in managing future efforts. Government Accountability Office, Report to the Chairman, Committee on Resources, House of Representatives, GAO-06-353

45. Keane RM, Crawley MJ. Exotic plant invasions and the enemy release hypothesis. Trends Ecol Evol. 2002;17:164-70.

46. Shea K, Chesson P. Community ecology theory as a framework for biological invasions. Trends Ecol Evol. 2002;17:170-6.

47. Hajek AE, Humber RA, Elkinton JS, May B, Walsh RA, Silver JC. Allozyme and RFLP analyses confirm Entomophaga maimaiga responsible for 1989 epizootics in North American gypsy moth populations. Proc Natl Acad Sci U S A. 1990;87:697982.

48. Torchin ME, Lafferty KD, Dobson AP, McKenzie VJ, Kuris AM. Introduced species and their missing parasites. Nature. 2003;421: 628-30.

49. Fernald $\mathrm{CH}$, Kirkland AH. The brown tailed moth, Euproctis chrysorrhoea: a report on the life history and habits of the imported brown-tail moth. Boston: Wright and Potter; 1903.

50. Burgess AF. Controlling the gipsy $[$ sic $]$ moth and the browntail moth. Washington, D.C.: United States Department of Agriculture Farmer's Bulletin 1335; 1923.

51. Burgess AF, Crossman SS (1929) Imported insect enemies of the gypsy moth and the brown-tail moth. USDA Technical Bulletin 86, Washington, D.C., USA

52. Elkinton JS, Parry D, Boettner GH. Implicating an introduced generalist parasitoid in the invasive browntail moth's enigmatic demise. Ecology. 2006;87:2664-72.

53. Colautti RI, Ricciardi A, Grigorovich IA, MacIsaac HJ. Is invasion success explained by the enemy release hypothesis? Ecol Lett. 2004;7:721-33.

54. Desurmont GA, Donoghue MJ, Clement WL, Agrawal AA. Evolutionary history predicts plant defense against an invasive pest. Proc Natl Acad Sci U S A. 2011;108:7070-4. doi:10.1073/ pnas. 1102891108.

55. Herms DA, Mattson WJ. The dilemma of plants: to grow or defend. Q Rev Biol. 1992;67:283-335.

56. Gatehouse JA. Plant resistance towards insect herbivores: a dynamic interaction. New Phytol. 2002;156:145-69.

57. Levin DA. The chemical defenses of plants to pathogens and herbivores. Annu Rev Ecol Syst. 1976;7:121-59.

58. Tallamy DW, Raupp MJ. Phytochemical induction by herbivores. New York: Wiley-Interscience; 1991.

59. Karban R, Myers JH. Induced plant responses to herbivory. Annu Rev Ecol Syst. 1989;20:331-48.

60. Turlings TCJ, Loughrin JH, McCall PJ, Rose USR, Lewis WJ, Tumlinson JH. How caterpillar-damaged plants protect themselves by attracting parasitic wasps. Proc Natl Acad Sci U S A. 1995;92:4169-74.

61. Després L, David J-P, Gallet C. The evolutionary ecology of insect resistance to plant chemicals. Trends Ecol Evol. 2007;22:298 307.

62. Raffa KF, Berryman AA. The role of host plant resistance in the colonization behaviour and ecology of bark beetles. Ecol Monogr. 1983;53:27-49. 
63. Eyles A, Jones J, Riedl K, Cipollini D, Schwartz S, Chan K, et al. Comparative phloem chemistry of Manchurian (Fraxinus mandshurica) and two North American ash species (Fraxinus americana and Fraxinus pennsylvanica). J Chem Ecol. 2007;33: $1430-48$.

64. Raffa KR, Powell EN, Townsend PA. Temperature-driven range expansion of an irruptive insect heightened by weakly coevolved plant defenses. Proc Natl Acad Sci U S A. 2013;110:2193-8.

65. Nielsen DG. Exploiting natural resistance as a management tactic for landscape plants. Fla Entomol. 1989;72:413-8.

66. Poland TM, McCullough DG. Emerald ash borer: invasion of the urban forest and the threat to North America's ash resource. J For. 2006;104:118-24.

67. Rebek EJ, Herms DA, Smitley DA. Interspecific variation in resistance to emerald ash borer (Coleoptera: Buprestidae) among North American and Asian ash (Fraxinus spp.). Environ Entomol. 2008;37:242-6.

68. Anagnostakis SL. Chestnut blight: the classical problem of an introduced pathogen. Mycologia. 1987;79:23-37.

69.• Loo JA. Ecological impacts of non-indigenous invasive fungi as forest pathogens. Biol Invasions. 2009;11:81-96. Provides an extensive review of the ecological consequences of non-native forest fungal pathogens.

70. Diskin M, Steiner KC, Hebard FV. Recovery of American chestnut characteristics following hybridization and backcross breeding to restore blight-ravaged Castanea dentata. For Ecol Manag. 2006;223:439-47.

71. Tobin PC, Bai BB, Eggen DA, Leonard DS. The ecology, geopolitics, and economics of managing Lymantria dispar in the United States. Integr J Pest Manag. 2012;53:195-210.

72. Lovett GM, Christenson LM, Groffman PM, Jones CG, Hart JE, Mitchell MJ. Insect defoliation and nitrogen cycling in forests. Bioscience. 2002;52:335-41.

73. Wallner WE. Factors affecting insect population dynamics: differences between outbreak and non-outbreak species. Annu Rev Entomol. 1987;32:317-40.

74.•• Gandhi JKJ, Herms DA. Direct and indirect effects of alien insect herbivores on ecological processes and interactions in forests of eastern North America. Biol Invasions. 2010;12:389-405. Provides an extensive review of the ecological consequences of non-native forest insects.

75. Randolph KC, Rose AK, Oswalt CM, Brown MJ. Status of black walnut (Juglans nigra L.) in the eastern United States in light of the discovery of thousand cankers disease. Castanea. 2013;78:214.

76. Tobin PC, Kean JM, Suckling DM, McCullough DG, Herms DA, Stringer LD. Determinants of successful arthropod eradication programs. Biol Invasions. 2014;16:401-14.

77. Liebhold AM, Tobin PC. Growth of newly established alien populations: comparison of North American gypsy moth colonies with invasion theory. Popul Ecol. 2006;48:253-62.

78. Persad AB, Tobin PC (2015) Evaluation of ash tree symptoms associated with emerald ash borer Infestation in urban forests. Arbor Urban For (In Press)

79. Haight RG, Homans FR, Horie T, Mehta SV, Smith DJ, Venette RC. Assessing the cost of an invasive forest pathogen: a case study with oak wilt. Environ Manag. 2011;47:506-17.

80. Sydnor TD, Bumgardner M, Todd A. The potential economic impacts of emerald ash borer (Agrilus planipennis) on Ohio, U.S., communities. Arbor Urban For. 2007;33:48-54.
81. Bigsby KM, Ambrose MJ, Tobin PC, Sills EO. The cost of gypsy moth sex in the city. Urban For Urban Green. 2014;13:459-68.

82. Nowak DJ, Crane DE, Dwyer JF. Compensatory value of urban trees in the United States. J Arboric. 2002;28:194-9.

83. Ranger CM, Tobin PC, Reding ME (2015) Ubiquitous volatile compound facilitates efficient host location by a non-native ambrosia beetle. Biol Invasions (In Press)

84. Fraedrich SW, Harrington TC, Rabaglia RJ, Ulyshen MD, Mayfield AEI, Hanula JL, et al. A fungal symbiont of the redbay ambrosia beetle causes a lethal wilt in redbay and other Lauraceae in the southeastern USA. Plant Dis. 2008;92:215-24.

85. Ploetz RC, Hulcr J, Wingfield MJ, de Beer ZW. Destructive tree diseases associated with ambrosia and bark beetles: black swan events in tree pathology? Plant Dis. 2013;95:856-72.

86. Hulcr J, Dunn RR. The sudden emergence of pathogenicity in insect-fungus symbioses threatens naive forest ecosystems. P Roy Soc B Biol Sci. 2011;278:2866-73.

87. Wratten S, Sandhu H, Cullen R, Costanza R, editors. Ecosystem services in agricultural and urban landscapes. UK: WileyBlackwell Oxford; 2013.

88. Redman AM, Scriber JM. Competition between the gypsy moth, Lymantria dispar, and the northern tiger swallowtail, Papilio canadensis: interactions mediated by host plant chemistry, pathogens, and parasitoids. Oecologia. 2000;125:218-28.

89. Herms DA. Assessing options for managing gypsy moth. Pestic Outlook. 2003;14:14-8.

90. McCullough DG, Mercader RJ. Evaluation of potential strategies to SLow Ash Mortality (SLAM) caused by emerald ash borer (Agrilus planipennis): SLAM in an urban forest. Int J Pest Manag. 2012;58:9-23.

91. Martinat PJ, Coffman CC, Dodge K, Cooper RJ, Whitmore RC. Effect of diflubenzuron on the canopy arthropod community in a central Appalachian forest. J Econ Entomol. 1988;81:261-7.

92. Cooper RJ, Dodge KM, Martinat PJ, Donahoe SB, Whitmore RC. Effect of diflubenzuron application on eastern deciduous forest birds. J Wildl Manag. 1990;54:486-93.

93. Manderino R, Crist TO, Haynes KJ. Lepidoptera-specific insecticide used to suppress gypsy moth outbreaks may benefit nontarget forest Lepidoptera. Agric For Entomol. 2014;16:359-68.

94. Clark KL, Skowronski N, Hom J. Invasive insects impact forest carbon dynamics. Glob Chang Biol. 2010;16:88-101.

95. Grady AE, Scanlon TM, Galloway JN. Declines in dissolved silica concentrations in western Virginia streams (1988-2003): gypsy moth defoliation stimulates diatoms? J Geophys Res. 2007;112: G01009.

96. Hicke JA, Allen CD, Desai AR, Dietze MC, Hall RJ, Hogg EH, et al. Effects of biotic disturbances on forest carbon cycling in the United States and Canada. Glob Chang Biol. 2012;18:7-34.

97. Webb JR, Cosby BJ, Deviney Jr FA, Eshleman KN, Galloway JN. Change in the acid-base status of an appalachian mountain catchment following forest defoliation by the gypsy moth. Water Air Soil Pollut. 1995;85:535-40.

98. Dale VH, Joyce LA, McNulty S, Neilson RP, Ayres MP, Flannigan $\mathrm{MD}$, et al. Climate change and forest disturbances. Bioscience. 2001;51:723-34.

99. Eschtruth AK, Battles JJ. Assessing the relative importance of disturbance, herbivory, diversity, and propagule pressure in exotic plant invasion. Ecol Monogr. 2009;79:265-80.

100. Gómez-Aparicio L, Canham CD. Neighborhood models of the effects of invasive tree species on ecosystem processes. Ecol Monogr. 2008;78:69-86. 